\title{
Jak na počítač pro seniory se zaměřením na komunikační programy
}

\author{
Dagmar Kruliková, Tereza Nejepsová, Martin Rybák, \\ Jan Beníšek, Karel Heřman, Martin Pešek, Filip Rychetský, \\ Oldřich Myslivec, Tomáš Feglar
}

Vedoucí práce: doc. Ing. Vlasta Střížová, CSc., Ing. Jan Klas

Tým UniDuch vytvořil semestrální projekt Jak na počítač pro seniory - se zaměřením na komunikační programy v rámci předmětu 4SA426 Prezentace a komunikace informací vedeném doc. Ing. Vlastou Střížovou, CSc. a Ing. Janem Klasem v letním semestru školního roku 2006/2007.

Cílem projektu bylo vytvoření výukových materiálů pro práci s počítačem pro uživatele třetího věku. Na základě provedeného průzkumu a zjištěných nepokrytých oblastí bylo zvoleno zaměření na komunikační programy.

Mezi vedlejší cíle projektu, zaměřené na praktické zkušenosti a dovednosti, patř̌ila práce ve větším týmu, rízení tohoto týmu, nastavení vnitřní organizační struktury a standardů komunikace, vedení projektové kanceláře a $\mathrm{v}$ neposlední řadě také procvičení komunikačních a prezentačních dovedností.

Výstup projektu se skládá ze sedmi svazků:

- Príručka Skype,

- Př́ručka MSN Messenger,

- Př́ručka ICQ 5.1,

- Př́ručka Užitečné programy - přehled,

- Dokumentace projektu Uniduch,

- Př́lohy projektu Uniduch,

- Slovník pojmů projektu Uniduch.

Př́ručky ke komunikačním programům Skype, MSN Messenger a ICQ 5.1 jsou umístěny každá v samostatném svazku. Vedlejším výstupem je rovněž př́ručka Užitečné programy - přehled, která obsahuje stručný popis zajímavých programů, které tým doporučuje pozornosti cílové skupiny.

Projektová dokumentace se skládá ze tř́ svazků - Dokumentace projektu UniDuch, Př́lohy projektu UniDuch a Slovník pojmů projektu UniDuch. Svazek Dokumentace projektu UniDuch obsahuje cíle projektu, organizační strukturu týmu, způsob a výsledky úvodního průzkumu, finanční rozpočet, ... Popisy pozic $\mathrm{v}$ týmu, zápisy z jednání a průběžné reporty jsou umístěny ve svazku Př́lohy projektu UniDuch. Tým rovněž vytvořil po- 
měrně rozsáhlý terminologický slovník pojmů používaných v rámci projektu, který se nachází v samostatném svazku (Slovník pojmů projektu UniDuch).

$\mathrm{Na}$ řešení projektu tým rovněž částečně spolupracoval s Univerzitou třetího věku Vysoké školy ekonomické v Praze, a to prostřednictvím paní Mgr. Lei Nedomové.

Výstupy projektu jsou v papírové podobě k dispozici k nahlédnutí u Ing. Jana Klase, Katedra systémové analýzy, místnost NB 447 (v konzultačních hodinách). Tým UniDuch rovněž vytvořil webové stránky projektu, které jsou dostupné na adrese http://www.uniduch.wz.cz/ (poslední kontrola dne 31. 5. 2007). 